\title{
Curcumin inhibits bovine herpesvirus type 1 entry into MDBK cells
}

\author{
L. ZHU ${ }^{1,2}$, X. DING ${ }^{3}$, D. ZHANG ${ }^{1,2}$, CH. YUAN ${ }^{1,2}$, J. WANG ${ }^{1,2}$, E. NDEGWA ${ }^{4}$, G. ZHU ${ }^{1,2^{*}}$ \\ ${ }^{1}$ College of Veterinary Medicine, Yangzhou University, 48 Wenhui East Road, Yangzhou 225009, P. R. China; ${ }^{2} J i a n g s u$ Co-innovation \\ Center for Prevention and Control of Important Animal Infectious Diseases and Zoonoses, 48 Wenhui East Road, Yangzhou, \\ 225009, P. R. China; ${ }^{3}$ The test center of Yangzhou University, 48 Wenhui East Road, Yangzhou, 225009, P. R. China; ${ }^{4}$ Department of \\ Agriculture, School of Agriculture, Fisheries and Human Sciences, University of Arkansas at Pine Bluff, \\ 1200 University Dr Pine Bluff, AR 71601, USA
}

Received December 23, 2014; revised February 23, 2015; accepted July 29, 2015

\begin{abstract}
Summary. - The generation of antiviral drugs from herbs and other natural resources with traditionally longconfirmed effects is an efficient approach. So far, no herb or components from herbs that could inhibit bovine herpesvirus type 1 (BoHV-1) replication have been described. In this study, the antiviral effect of curcumin, a natural phenolic constituent of the spice turmeric, on BoHV-1 replication was evaluated in cell culture. We demonstrated that curcumin impairs BoHV-1 viral particles and affects the virus post-binding entry process. Furthermore, curcumin upregulated the proportion of the plasma membrane adopting a lipid raft conformation in MDBK cells, which supported the previous reports that curcumin can modulate the lipid bilayer. Though the antiviral mechanism of curcumin on BoHV-1 needs further study, we identified for the first time a component from herb that could inhibit BoHV-1 replication, in vitro.
\end{abstract}

Keywords: BoHV-1; curcumin; lipid raft; virus entry

\section{Introduction}

Curcumin (diferuloylmethane), a natural polyphenolic compound derived from turmeric (Curcuma Longa) is a widely used spice and coloring agent in food (Goel et al., 2008; Liu et al., 2014). It is documented to have a broad spectrum of biological and pharmacological activities, such as anti-inflammatory and anti-oxidative properties, free radical removal, and anti-cancer activity (Asher and Spelman, 2013). Traditionally, it was commonly applied in many therapeutic remedies, either alone or in conjunction with other natural

*Corresponding author. E-mail: yzgqzhu@yzu.edu.cn; phone: +86-514-87311374.

Abbreviations: BoHV-1 = bovine herpesvirus type 1; CTBFITC = fluorescent cholera toxin B subunit; DMSO = dimethyl sulfoxide; $\mathrm{HSV}=$ herpes simplex virus; $\mathrm{M} \beta \mathrm{CD}=$ methyl- $\beta$ cyclodextrin; $\mathrm{MDBK}=$ Madin-Darby bovine kidney; $\mathrm{MOI}=$ multiplicity of infection; MTT = 3-(4,5-Dimethylthiazol-2-yl)-2,5diphenyl tetrazolium bromide; p.i. $=$ post infection; $\mathrm{TCID}_{50}=$ tissue culture infection dose $50 \%$ substances in China, India and South East Asia (Aggarwal et al., 2007; Araujo and Leon, 2001; Limtrakul et al., 2001). Currently, Curcuma longa and curcumin have been subjected to a variety of antimicrobial investigations. Curcumin decreased the replication of multiple viruses in vitro, such as rift valley fever virus 2 , respiratory syncytial virus, pseudorabies virus, influenza virus, coxsackievirus, hepatitis B virus, hepatitis $\mathrm{C}$ virus, herpes simplex virus (HSV), human immunodeficiency virus type 1 and Japanese encephalitis virus (Zhang et al., 2014). However, the antiviral effect of curcumin was rarely documented in the field of veterinary (animal) viruses.

BoHV-1 is an enveloped virus (the genus Varicellovirus, the family Herpesviridae, the subfamily Alphaherpesvirinae), which infects cattle of all ages and breeds, and causes considerable economic losses to the cattle industry due to the virus-induced respiratory inflammation, decrease in milk yield, reduced fertility and abortions (Jones and Chowdhury, 2007; Muylkens et al., 2007; Sinani et al., 2014; Straub, 1975; Tikoo et al., 1995; Turin et al., 1999). There is currently no effective vaccine to fully protect from field BoHV-1 infection (OIE, 2004), and no effective antiviral intervention is clini- 
cally available in case of BoHV-1 infection. Though herbs are widely applied to treat various bovine diseases with good results, a herb or components of a herb that would inhibit BoHV-1 replication are rarely reported.

In this study, we demonstrated that curcumin originating from a herb possessed strong antiviral effect on BoHV-1 in vitro. Curcumin increased the cellular membrane lipid raft formation. Whether the regulation of lipid raft formation accounts for the antiviral mechanism of curcumin needs further research, nevertheless, we reported here an effective herbal compound that could inhibit BoHV-1 replication in vitro.

\section{Materials and Methods}

Virus and cell cultures. MDBK cells were maintained at $37^{\circ} \mathrm{C}$ in $5 \% \mathrm{CO}_{2}$ in DMEM (Gibco BRL) supplemented with $10 \%$ horse serum (HyClone), and routinely passaged whenever they became confluent. The Coloradol strain of BoHV-1 was used for this study (Wang et al., 2003). Viruses were propagated in MDBK cells with DMEM (without serum). The collected viruses were aliquoted, titrated and stored at $-70^{\circ} \mathrm{C}$ until use.

Reagents. Curcumin, an analytical standard (chemical formula $[\mathrm{HOC} 6 \mathrm{H} 3(\mathrm{OCH} 3) \mathrm{CH}=\mathrm{CHCO}] 2 \mathrm{CH} 2)$, provided by Sigma-Aldrich (St. Louis, MO), was dissolved in dimethyl sulfoxide (DMSO), and aliquots were stored at $-80^{\circ} \mathrm{C}$. Water-soluble reagents $3-(4,5-$ Dimethylthiazol-2-yl)-2,5-diphenyl tetrazolium bromide (MTT),

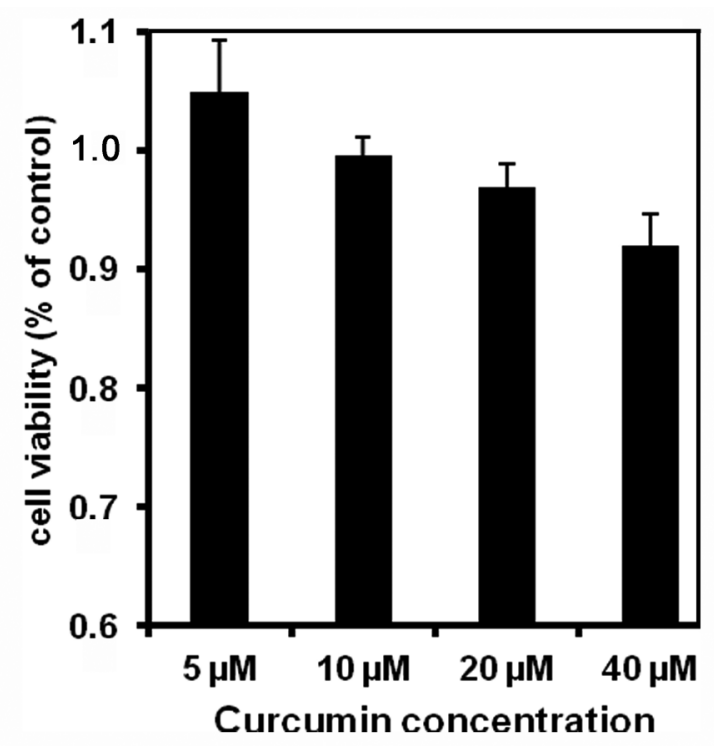

Fig. 1

Cytotoxicity of curcumin in MDBK cells

MDBK cell were treated with curcumin at indicated concentrations for 24 hr at $37^{\circ} \mathrm{C}$ or incubated with culture medium containing DMSO as a control and then subjected to an MTT reduction assay to determine cell viability. Experiments were repeated three times, and the error bars indicate the standard deviations of three independent experiments.
Methyl- $\beta$-cyclodextrin $(\mathrm{M} \beta \mathrm{CD})$, and fluorescent cholera toxin $\mathrm{B}$ subunit (CTB-FITC) were also purchased from Sigma-Aldrich (St. Louis, MO).

Cytotoxicity assay. Monolayers of MDBK cells seeded in 96-well plates were incubated with curcumin at concentrations 5, 10, 20 and $40 \mu \mathrm{mol} / \mathrm{l}$ at $37^{\circ} \mathrm{C}$ for $24 \mathrm{hr}$, and the cytotoxicity was determined by MTT reduction assay as previously described (Zhu et al., 2010). The mean optical density of the control wells treated with DMSO was assigned as a value of $100 \%$.

Assay for the variation of cellular lipid raft. Alteration of cellular lipid raft by curcumin was assessed by flow cytometry assay. MDBK cells seeded in six-well plates in three replicates were mock-treated or treated with $2.5,5$ and $10 \mu \mathrm{mol} / \mathrm{l}$ curcumin, respectively, for $1 \mathrm{hr}$ at $37^{\circ} \mathrm{C}$. The cells were detached and washed three times with icecold PBS, followed by incubation with CTB-FITC at $1 \mathrm{mg} / \mathrm{ml}$ in serum-free DMEM for 30 min on ice. After washing twice, the cells were subjected to analysis using BectonDickinson FACSCalibur flow cytometer with 10,000 events collected, and data were analyzed using FlowJo software, version 7.1.3.

Inhibition of viral replication by curcumin. MDBK cells seeded into 24-well plates were incubated overnight in a $\mathrm{CO}_{2}$ incubator at $37^{\circ} \mathrm{C}$. The medium was replaced with fresh DMEM with either DMSO or curcumin at the concentrations of 5, 10 and $20 \mu \mathrm{mol} / \mathrm{l}$, resp., and incubated for $1 \mathrm{hr}$ at $37^{\circ} \mathrm{C}$, followed by infection with BoHV-1 at an multiplicity of infection (MOI) of 1 . After treatment with citric buffer and extensive washing with phosphate-buffered saline (PBS), DMEM medium (400 $\mu \mathrm{l})$ with or without chemicals was added to each well. After $24 \mathrm{hr}$ of incubation, the cells were subjected to two freeze-thaw cycles, and the virus yield was titrated by TCID $_{50}$ assay (Zhu et al., 2010). To evaluate whether serum affected the antiviral activity of curcumin, the experiment was performed similarly except that $2 \%$ horse serum was added to DMEM.

The determination of viricidal effect of curcumin. BoHV-1- infected cells were exposed to solvent DMSO or curcumin at the concentrations of $2.5,5$ and $10 \mu \mathrm{mol} / \mathrm{l}$ for $1 \mathrm{hr}$ at $37^{\circ} \mathrm{C}$. Following the treatment, viral infectivity was determined by the $\mathrm{TCID}_{50}$ assay.

Virus attachment assay. Monolayer of MDBK cells seeded in 6-well plates was pretreated with solvent DMSO or curcumin at a concentration of $10 \mu \mathrm{mol} / \mathrm{l}$ for $1 \mathrm{hr}$ at $37^{\circ} \mathrm{C}$, and then were exposed to BoHV-1 at an MOI of 100 at $4^{\circ} \mathrm{C}$ for $1 \mathrm{hr}$ in the presence of solvent or curcumin. Unbound virus particles were removed by extensive washing with ice-cold PBS. After two freeze-thaw cycles, the cell-bound virus was titrated by $\mathrm{TCID}_{50}$ assay.

Time-of-addition assay. Confluent MDBK cells in 24-well were infected with BoHV-1 at MOI of 1 . The tested compound was added to cells at $10 \mu \mathrm{mol} / \mathrm{l}$ at $1 \mathrm{hr}$ pre-infection $(-1 \mathrm{hr})$, during infection $(0 \mathrm{hr})$, and $1 \mathrm{hr}$ post-infection (p.i.) (+1 hr). At $24 \mathrm{hr}$ p.i. the virus yields were titrated with $\mathrm{TCID}_{50}$ assay. Fig. 4 a. shows the results in a diagram for the four different experimental treatment manners.

Statistical analysis. Results were expressed as mean value \pm SD. The Student's $t$-test was used to identify statistically significant differences between treatment means. Significance was accepted at $\mathrm{P}<0.05$. 


\section{Results}

\section{Cytotoxicity of curcumin}

MTT assays were performed to select the proper concentration of curcumin with minimal cytotoxicity in MDBK cells. Concentrations of curcumin ranging from 5 to 40 $\mu \mathrm{mol} / \mathrm{l}$ were tested. The cytotoxicity of curcumin in MDBK

(a)

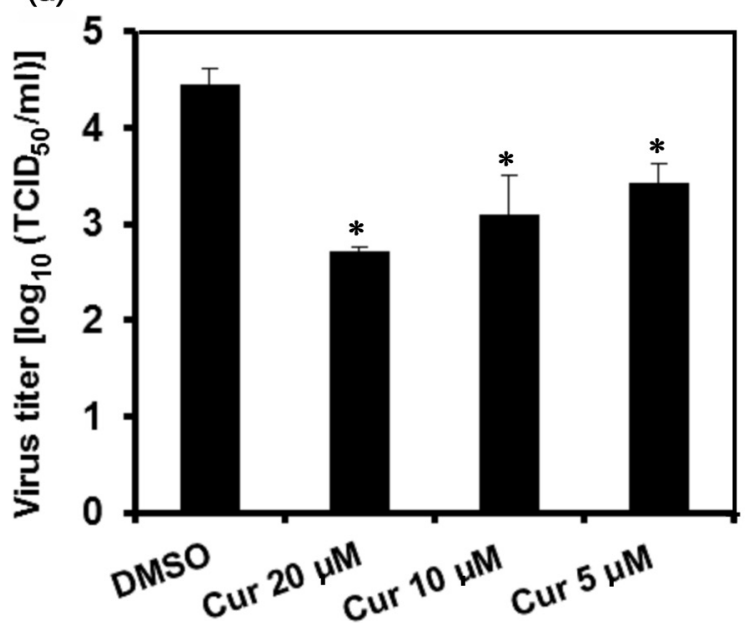

(b)

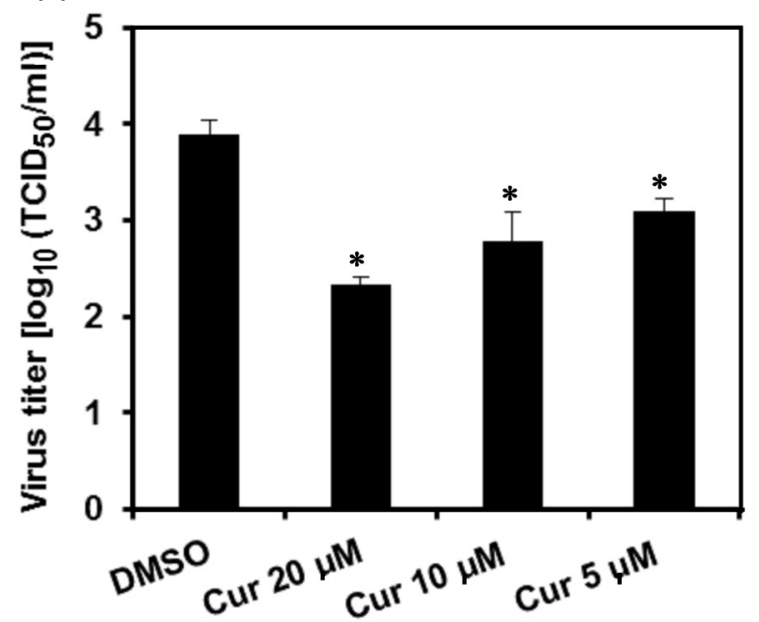

Fig. 2

Antiviral activity of curcumin against BoHV-1 infection in MDBK cells

MDBK cells were mock pretreated with DMSO or pretreated with curcumin at the concentration of 20,10 and $5 \mu \mathrm{mol} / \mathrm{l}$, respectively. These cells were subjected to BoHV-1 infection at an MOI of 1 for $1 \mathrm{hr}$ with or without treatment of curcumin. After extensive washing with PBS, cells were further cultured for $24 \mathrm{hr}$ with the medium containing curcumin or the vehicle. The virus yields were then titrated by the TCID $_{50}$ assay. During the infection, horse serum of $2 \%(\mathrm{v} / \mathrm{v})$ was applied (b) or not (a). The viral titers were determined by $\mathrm{TCID}_{50}$ method $24 \mathrm{hr}$ p.i. The assays were performed in duplicate and data represent means $\pm \mathrm{SD}$. ${ }^{\star} \mathrm{P}<0.05$. cells was dose-dependent. Treatment of MDBK cells with 20 and $40 \mu \mathrm{mol} / \mathrm{l}$ of curcumin reduced the cell viability to $96.9 \%$ and $91.9 \%$, respectively, compared to the control, while curcumin at a concentration of less than $10 \mu \mathrm{mol} / \mathrm{l}$ showed minor toxicity to MDBK cells (Fig. 1). Thus, the concentration of less than $10 \mu \mathrm{mol} / \mathrm{l}$, unless otherwise specified, was adopted for the subsequent study.

\section{Antiviral activity of curcumin}

The antiviral effect of curcumin at various concentrations was evaluated. MDBK cells were incubated with 5, 10 and $20 \mu \mathrm{mol} / \mathrm{l}$ of curcumin throughout the BoHV-1 infection $(\mathrm{MOI}=1)$, including a pretreatment step for $1 \mathrm{hr}$, during and after virus inoculation steps. The virus production was assessed with TCID $_{50}$ assay $24 \mathrm{hr}$ p.i. As shown in Fig. 2a, curcumin impaired the virus propagation in a dose-dependent manner. Treatment of cells with curcumin at a concentration of 5,10 and $20 \mu \mathrm{mol} / \mathrm{l}$ resulted in a 1.01, 1.35 and $1.74 \mathrm{log}$ reduction in virus yield, respectively.

Some components in the serum may counteract the antiviral activity of curcumin. Therefore, $2 \%$ horse serum was introduced to the medium during BoHV-1 infection with or without curcumin. As indicated in Fig. 2b, treatment of cells with curcumin at the concentration of 5,10 and 20 $\mu \mathrm{mol} / \mathrm{l}$ resulted in a $0.80,1.11$ and $1.56 \log$ reduction in virus yield, respectively. Obviously, curcumin significantly inhibited BoHV-1 replication $(\mathrm{P}<0.05)$ even in the presence of serum.

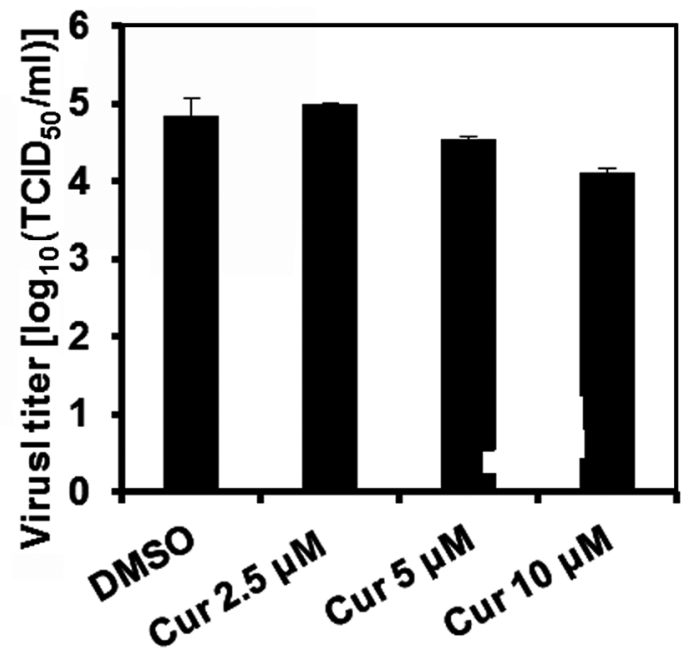

Fig. 3

Curcumin exhibited virucidal effect on BoHV-1

Virus stocks were exposed to curcumin at various concentrations or solvent at $37^{\circ} \mathrm{C}$ for $1 \mathrm{hr}$. Subsequently, the viruses were titrated by the $\mathrm{TCID}_{50}$ assay in MDBK cells. The assay was performed in duplicate and data represent means \pm SD. ${ }^{\star} \mathrm{P}<0.05$. 


\section{Viricidal effect of curcumin on BoHV-1}

To analyze whether curcumin directly inactivates BoHV-1 viral particles, the virions were treated with curcumin at various concentrations or with solvent at for $1 \mathrm{hr} 37^{\circ} \mathrm{C}$. Subsequently, the viruses were titrated using the $\mathrm{TCID}_{50}$ assay. As indicated in Fig. 3, the exposure of BoHV-1 to curcumin resulted in viricidal effect in a dose-dependent manner. Though the reduction of virus titer by $10 \mu \mathrm{mol} / \mathrm{l}$ of curcumin treatment was only by $0.73 \mathrm{log}$, the difference was statistically significant $(\mathrm{P}<0.05)$.

\section{Curcumin affected BoHV-1 entry into MDBK cells}

Since curcumin was established to have anti-BoHV-1 activity, we performed a time-of-addition analysis to pinpoint the $\operatorname{step}(s)$ in which virus infection was affected. Curcumin was applied as depicted in Fig. 4a. When employed at pre-

$\mathbf{A}$

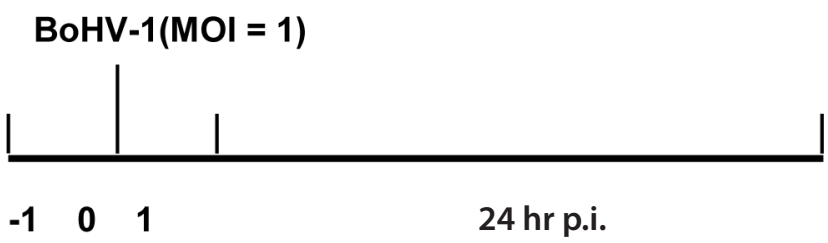

1 DMSO

2 Curcumin

3 Curcumin

4 Curcumin

(b) 5

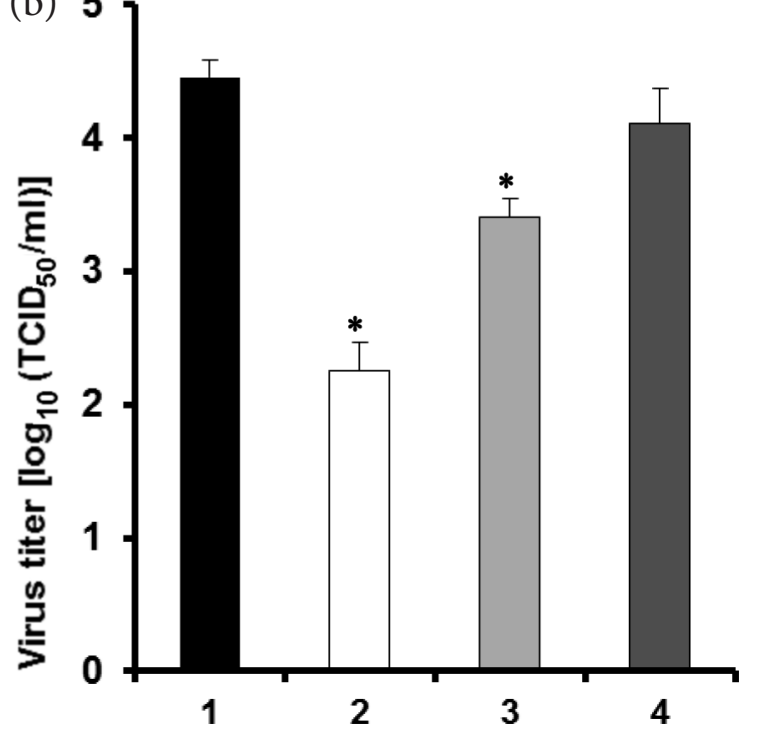

(c)

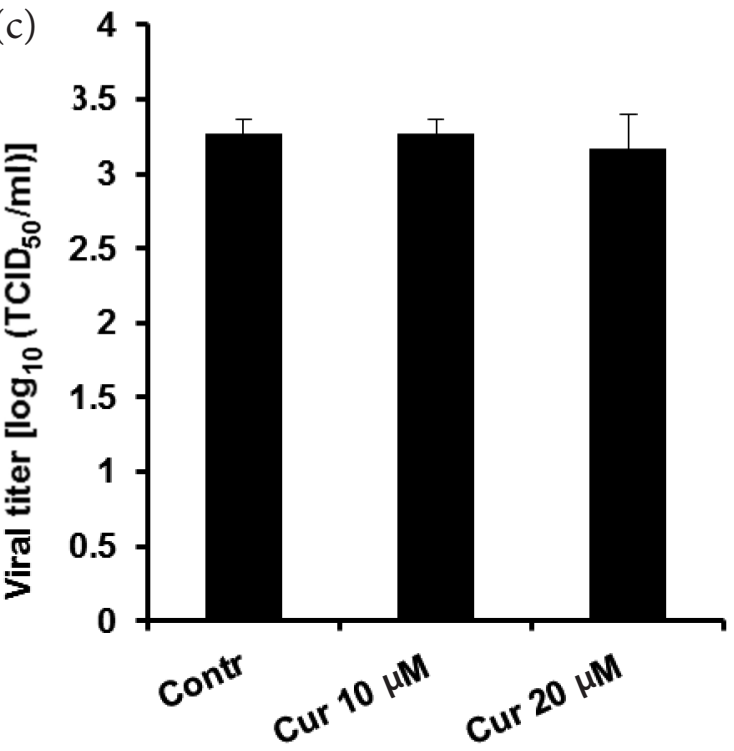

Fig. 4

Antiviral effect of curcumin on different steps of BoHV-1 infectious cycle

MDBK cells infected with BoHV-1 at an MOI of 1 were mock-treated with DMSO or treated with curcumin at different steps of infection. (a) Diagram showing four different experimental conditions: 1) DMSO treatment from -1 to $24 \mathrm{hr}$ p.i., 2) curcumin treatment from -1 to $24 \mathrm{hr}$ p.i., 3) curcumin treatment from -1 to $1 \mathrm{hr}$ p.i., 4) curcumin treatment from 1 to $24 \mathrm{hr}$ p.i. (b) BoHV-1 infection under four experimental conditions as described in Fig. 4 a. Virus titer was determined at $24 \mathrm{hr}$ p.i. by TCID assay. (c) Virus binding assay. MDBK cells were mock treated or treated with curcumin at 10 and 20 $\mu \mathrm{mol} / \mathrm{l}$ for $1 \mathrm{hr}$, and then binding of BoHV-1 to the cells was allowed at $4^{\circ} \mathrm{C}$ for $1 \mathrm{hr}$. After extensive washes with ice-cold PBS, the amount of cell-associated virus was titrated by $\operatorname{TCID}_{50}$ assay. The assays were performed in duplicate and data represent means $\pm \mathrm{SD}$. ${ }^{\star} \mathrm{P}<0.05$. 
entry and entry stage (from -1 to $1 \mathrm{hr}$ p.i.), $10 \mu \mathrm{mol} / \mathrm{l}$ of curcumin was able to significantly inhibit virus production $(\mathrm{P}<0.05)$. In contrast, only minor effect of curcumin on BoHV-1 replication was observed at the post-entry stage (1 to $24 \mathrm{hr}$ p.i.). Obviously, curcumin affected early entry step of the virus (Fig. 4b).

To determine whether curcumin blocked virus binding, MDBK cells pretreated with curcumin were exposed to viral particles along with DMSO or curcumin at $4^{\circ} \mathrm{C}$ for $1 \mathrm{hr}$. After extensive washing, the cells were subjected to two freezethaw cycles and the cell-attached virus was titrated by TCID $_{50}$ assay. Neither $10 \mu \mathrm{mol} / 1$ nor $20 \mu \mathrm{mol} / \mathrm{l}$ curcumin showed inhibitory effect on virus binding under these conditions (Fig. 4c). Taken together, curcumin mainly affects BoHV-1 post-binding entry process.

\section{Effect of curcumin on the cell membrane lipid raft for- mation}

We previously reported that the disruption of lipid raft domains associated with BoHV-1 entry process. As we found here that curcumin affected the virus entry process, we wondered whether curcumin could disrupt lipid raft formation, resulting in the inhibition of virus entry process. MDBK cells pretreated with 5 and $10 \mu \mathrm{mol} / \mathrm{l}$ of curcumin for $1 \mathrm{hr}$ were stained with fluorescence-labeled cholera toxin subunit B (CTB), which binds the raft-associated glycosphingolipid GM1, a marker of lipid raft domains. M $\beta C D$ was confirmed to specifically disrupt lipid raft formation though depletion of membrane cholesterol. Our results indicated that M $\beta C D$ significantly decreased the proportion of lipid raft domains in cell membrane, in contrast, $10 \mu \mathrm{mol} / \mathrm{l}$ of curcumin upregulated CTB binding to GM1 in MDBK cells (Fig. 5). Thus, we demonstrated that curcumin increased lipid raft formation in MDBK cells, but whether it blocked virus entry process needs further research.

\section{Discussion}

In China, herbs have been traditionally used for the treatment of various diseases with good performance. Therefore, the development of novel drugs from herbs is a viable approach. It is noteworthy that the exploration of antiviral agents from herbs in the field of veterinary viruses is far behind the field of human viruses.

BoHV-1 infects bovine and causes significant economic losses to the cattle industry worldwide. Though herbs are widely applied to treat various bovine disease with good results, a herb or herbal components that would inhibit BoHV-1 replication are rarely reported.

Curcumin, a natural polyphenol derived from the Curcuma longa L plant, is widely used as a herb in traditional

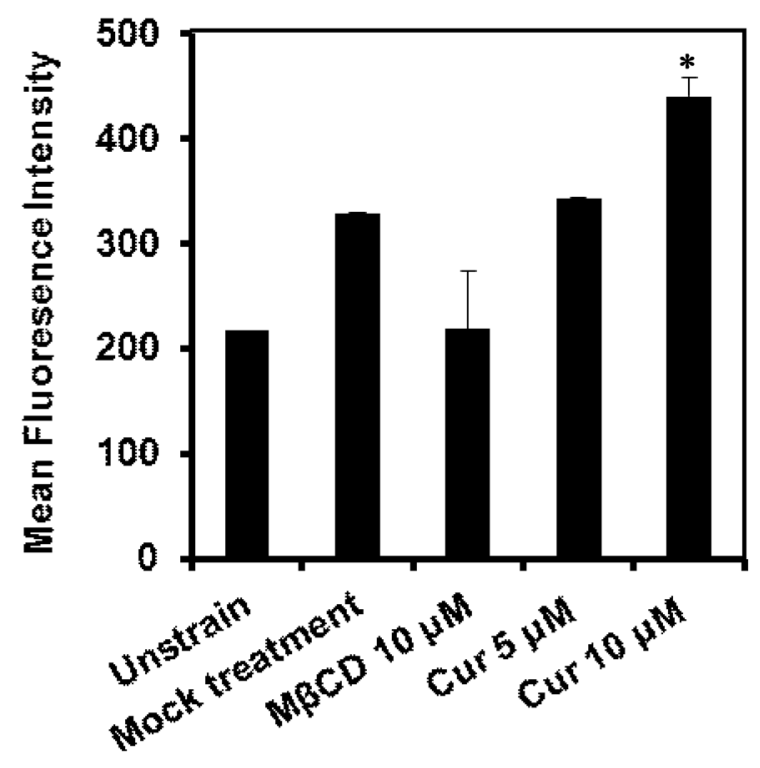

Fig. 5

Curcumin altered cellular lipid raft domains

MDBK cells were mock-treated with DMSO or treated with curcumin at indicated concentrations for $1 \mathrm{hr}$ at $37^{\circ} \mathrm{C}$, or were treated with $10 \mathrm{mmol} / \mathrm{l}$ $\mathrm{M} \beta \mathrm{CD}$ for $30 \mathrm{~min}$ as a control. The level of lipid raft formation was measured by detecting CTB-FITC binding to GM1 of the cells with Flow cytometry assay. Experiments were performed in duplicate and data represent means $\pm \mathrm{SD} .{ }^{\star} \mathrm{P}<0.05$.

Indian and Chinese medicine, with a variety of beneficial properties (Asher and Spelman, 2013). Antiviral activity of curcumin against both HSV-1 and HSV-2 had been demonstrated in previous reports (Bourne et al., 1999; Kutluay et al., 2008; Zandi et al., 2010). Since BoHV-1 belongs to the Alphaherpesvirinae subfamily and shares a number of biological properties with HSV-1 and HSV-2, we speculated that curcumin may also affect BoHV-1 replication.

Our results demonstrated that curcumin strongly inhibited BoHV-1 infection in MDBK cells in a dose-dependent manner. At all the concentrations analyzed, ranging from 5 to $20 \mu \mathrm{mol} / \mathrm{l}$, curcumin lowered the virus yield significantly $(\mathrm{P}<0.05)$. This antiviral activity was not substantially counteracted by components of the serum. Further investigation indicated that curcumin mainly interfered with the virus post-binding cell entry stages. No viral resistance was found after 5 passages in MDBK cells, as determined by virus titer assay (data not shown). Moreover, we found that curcumin has virucidal effect at the concentration of $10 \mu \mathrm{mol} / \mathrm{l}$, which resulted in a decrease of viral infectivity by $0.7 \log \mathrm{TCID}_{50}$ $(\mathrm{P}<0.05)$. Taken together, curcumin is a potential agent for protection against BoHV-1 infection in cell culture.

A number of studies have identified curcumin as a membrane-modulating agent, for example, it could alter lipid bilayer properties and influence structurally and functionally unrelated 
proteins, including a wide range of membrane proteins (Ingolfsson et al., 2007,2014), We have previously reported that cellular membrane lipid raft is crucial in mediating BoHV-1 entry into MDBK cells (Zhu et al., 2010). Here we demonstrated that curcumin affected BoHV-1 entry into MDBK cells. Thus, we wondered whether cellular membrane lipid raft was altered by curcumin. Raft-associated glycosphingolipid GM1 is a reliable marker for the detection of lipid raft domains with a method employing FITC-labeled CTB binding to GM1 (Carter et al., 2009; Janes et al., 1999; Jury et al., 2004). Using this detection method, we found that the proportion of the cellular membrane adopting lipid raft conformation was increased in MDBK cells following the treatment with $10 \mu \mathrm{mol} / \mathrm{l}$ curcumin. These would favor the interaction of curcumin with lipid bilayer, thus providing us new knowledge of curcumin-modulated lipid raft formation.

Multiple studies have evidenced the importance of lipid rafts for infection of cells by a variety of viruses (Suzuki and Suzuki, 2006). For the lack of an effective approach to increase the formation of lipid rafts, we could currently not provide a control to confirm that the antiviral actions of curcumin may be due to a membrane lipid raft-mediated mechanism. It is, however, highly possible that the upregulation of lipid raft formation by curcumin may result in an adverse environment for BoHV-1 entry into the target cells.

In summary, we identified the compound curcumin, originating from a traditionally used herb Curcuma longa $\mathrm{L}$, as an effective anti-BoHV-1 agent. Though the mechanism of inhibition of BoHV-1 replication by curcumin is unknown, we provided a hypothesis that the regulation of cellular membrane lipid raft formation by curcumin may account for the antiviral mechanism, which needs further studies in the future.

Acknowledgements. The authors are grateful to Dr. Leonard J. Bello, University of Pennsylvania, for providing the MDBK cells and the Colorado 1 strain of BoHV-1. This research was supported by Chinese National Science Foundation Grant (No. 31472172), the Priority Academic Program Development of Jiangsu Higher Education Institutions (PAPD), by the grant No. BE2014358 from the Science and Technology Department of Jiangsu province; grant No. 14KJA230001 from the Jiangsu High Education Basic Research; and 948 program grant No. 2011-G24 from Ministry of Agriculture of the People's Republic of China.

\section{References}

Aggarwal BB, Sundaram C, Malani N, Ichikawa H (2007): Curcumin: the Indian solid gold. Adv. Exp. Med. Biol. 595, 1-75. http://dx.doi.org/10.1007/978-0-387-46401-5 1

Araujo CC, Leon LL (2001): Biological activities of Curcuma longa L. Mem. Inst. Oswaldo Cruz 96, 723-728. http://dx.doi. org/10.1590/S0074-02762001000500026
Asher GN, Spelman K (2013): Clinical utility of curcumin extract. Altern. Ther. Health Med. 19, 20-22.

Bourne KZ, Bourne N, Reising SF, Stanberry LR (1999): Plant products as topical microbicide candidates: assessment of in vitro and in vivo activity against herpes simplex virus type 2. Antiviral Res. 42, 219-226. http://dx.doi. org/10.1016/S0166-3542(99)00020-0

Carter GC, Bernstone L, Sangani D, Bee JW, Harder T, James W (2009): HIV entry in macrophages is dependent on intact lipid rafts. Virology 386, 192-202. http://dx.doi. org/10.1016/j.virol.2008.12.031

Goel A, Kunnumakkara AB, Aggarwal BB (2008): Curcumin as "Curecumin": from kitchen to clinic. Biochem. Pharmacol. 75, 787-809. http://dx.doi.org/10.1016/j. bcp.2007.08.016

Ingolfsson HI, Koeppe RE 2nd, Andersen OS (2007): Curcumin is a modulator of bilayer material properties. Biochemistry 46, 10384-10391. http://dx.doi.org/10.1021/bi701013n

Ingolfsson HI, Thakur P, Herold KF, Hobart EA, Ramsey NB, Periole X, de Jong DH, Zwama M, Yilmaz D, Hall K, Maretzky T, Hemmings HC Jr., Blobel C, Marrink SJ, Kocer A, Sack JT, Andersen OS (2014): Phytochemicals perturb membranes and promiscuously alter protein function. ACS Chem. Biol. 9, 1788-1798. http://dx.doi. org $/ 10.1021 / \mathrm{cb} 500086 \mathrm{e}$

Janes PW, Ley SC, Magee AI (1999): Aggregation of lipid rafts accompanies signaling via the $\mathrm{T}$ cell antigen receptor. J. Cell. Biol. 147, 447-461. http://dx.doi.org/10.1083/ jcb.147.2.447

Jones C, Chowdhury S (2007): A review of the biology of bovine herpesvirus type 1 (BHV-1), its role as a cofactor in the bovine respiratory disease complex and development of improved vaccines. Anim. Health Res. Rev. 8, 187-205. http://dx.doi.org/10.1017/S146625230700134X

Jury EC, Kabouridis PS, Flores-Borja F, Mageed RA, and Isenberg DA (2004): Altered lipid raft-associated signaling and ganglioside expression in $\mathrm{T}$ lymphocytes from patients with systemic lupus erythematosus. J. Clin. Invest. 113, 1176-1187. http://dx.doi.org/10.1172/JCI200420345

Kutluay SB, Doroghazi J, Roemer ME, Triezenberg SJ (2008): Curcumin inhibits herpes simplex virus immediate-early gene expression by a mechanism independent of p300/CBP histone acetyltransferase activity. Virology 373, 239-247. http://dx.doi.org/10.1016/j.virol.2007.11.028

Limtrakul P, Anuchapreeda S, Lipigorngoson S, Dunn FW (2001): Inhibition of carcinogen induced c-Ha-ras and c-fos proto-oncogenes expression by dietary curcumin. BMC Cancer 1, 1. http://dx.doi.org/10.1186/1471-2407-1-1

Liu Y, Wang Y, Miao X, Zhou S, Tan Y, Liang G, Zheng Y, Liu Q, Sun J, Cai L (2014): Inhibition of JNK by compound C66 prevents pathological changes of the aorta in STZ-induced diabetes. J. Cell. Mol. Med. 18, 1203-1212. http://dx.doi. org/10.1111/jcmm. 12267

Muylkens B, Thiry J, Kirten P, Schynts F, Thiry E (2007): Bovine herpesvirus 1 infection and infectious bovine rhinotracheitis. Vet. Res. 38, 181-209. http://dx.doi.org/10.1051/ vetres:2006059 
Sinani D, Liu Y, Jones C (2014): Analysis of a bovine herpesvirus 1 protein encoded by an alternatively spliced latency related (LR) RNA that is abundantly expressed in latently infected neurons. Virology 464-465, 244-252. http:// dx.doi.org/10.1016/j.virol.2014.06.038

Straub OC (1975): Infectious bovine rhinotracheitis virus. History and recent developments. Dev. Biol. Stand. 28, 530-533.

Suzuki, T, and Suzuki, Y (2006): Virus infection and lipid rafts. Biol. Pharm. Bull. 29, 1538-1541. http://dx.doi.org/10.1248/ bpb.29.1538

Tikoo SK, Campos M, Babiuk LA (1995): Bovine herpesvirus 1 (BHV-1): biology, athogenesis, and control. Adv. Virus Res. 45, 191-223. http://dx.doi.org/10.1016/S0065-3527(08)60061-5

Turin L, Russo S, Poli G (1999): BHV-1: new molecular approaches to control a common and widespread infection. Mol. Med. 5, 261-284.
Wang L, Menon S, Bolin SR, Bello LJ (2003): A hepadnavirus regulatory element enhances expression of a type 2 bovine viral diarrhea virus E2 protein from a bovine herpesvirus 1 vector. J. Virol. 77, 8775-8782. http://dx.doi.org/10.1128/ IVI.77.16.8775-8782.2003

Zandi K, Ramedani E, Mohammadi K, Tajbakhsh S, Deilami I, Rastian Z, Fouladvand M, Yousefi F, Farshadpour F (2010): Evaluation of antiviral activities of curcumin derivatives against HSV-1 in Vero cell line. Nat. Prod. Commun. 5, 1935-1938.

Zhang Y, Wang Z, Chen H, Chen Z, Tian Y (2014): Antioxidants: potential antiviral agents for Japanese encephalitis virus infection. Int. J. Infect. Dis. 24, 30-36. http://dx.doi. org/10.1016/j.ijid.2014.02.011

Zhu L, Ding X, Tao J, Wang J, Zhao X, Zhu G (2010): Critical role of cholesterol in bovine herpesvirus type 1 infection of MDBK cells. Vet. Microbiol. 144, 51-57. http://dx.doi. org/10.1016/j.vetmic.2009.12.031 